\title{
PTEN and $\alpha$-SMA Expression and Diagnostic Role in Oral Submucous Fibrosis and Oral Squamous Cell Carcinoma with Concomitant Oral Submucous Fibrosis
}

\author{
Roshni Monteiroํㅜ Kaveri Hallikeri ${ }^{1}$, Archana Sudhakaran ${ }^{1}$ \\ ${ }^{1}$ Department of Oral and Maxillofacial Pathology and Oral Microbiology, SDM College of Dental Sciences and Hospital, \\ Dharwad, India.
}

\author{
Corresponding Author: \\ Kaveri Hallikeri \\ Department of Oral and Maxillofacial Pathology and Oral Microbiology \\ SDM College of Dental Sciences and Hospital \\ A constituent unit of Shri Dharmasthala Manjunatheshwara University \\ Sattur, Dharwad-580009, Karnataka \\ India \\ Phone: +919620657979 \\ E-mail:drcauveri2005@gmail.com
}

\begin{abstract}
Objectives: The diagnostic role and correlation between phosphatase and tensin homologue and alpha-smooth muscle actin in oral submucous fibrosis and oral squamous cell carcinoma with concomitant oral submucous fibrosis was analysed by this case control study. The mechanism by which phosphatase and tensin homologue controls myofibroblast expression was also evaluated.

Material and Methods: Overall, 10 normal mucosa, 30 oral submucous fibrosis (OSF) and 30 oral squamous cell carcinoma (OSCC) with OSF were stained immunohistochemically with phosphatase and tensin homologue (PTEN) and alpha-smooth muscle actin ( $\alpha$-SMA). Percentage positivity, pattern of expression was statistically compared using Pearson's Chi-square and Fischer exact tests. The correlation between markers was analysed using Spearman correlation.

Results: OSF and OSCC affected males predominantly with majority below 40 years and above 40 years of age respectively. Percentage of PTEN positive cells was statistically significant with gender $(\mathrm{P}=0.024)$ and $\alpha$-SMA distribution of pattern showed a significant correlation with habits $(\mathrm{P}=0.018)$. A significant decrease in nuclear PTEN positivity $(\mathrm{P}<0.001)$ and a gradual increase in $\alpha$-SMA cytoplasmic expression was noted from NM to OSF and OSCC. A statistically significant weak inverse correlation existed between PTEN and $\alpha$-SMA.

Conclusions: A reduced phosphatase and tensin homologue expression in oral submucous fibrosis makes it more prone for malignant transformation. An increase in stromal desmoplasia modifies differentiation, invasive and proliferative capacity of tumour cells. As phosphatase and tensin homologue functions through P-Akt pathway, P-Akt with phosphatase and tensin homologue could be a therapeutic target.
\end{abstract}

Keywords: immunohistochemistry; myofibroblast; oral cancer; oral submucous fibrosis; prognosis; tumor suppressor gene.

\author{
Accepted for publication: 4 March 2021 \\ To cite this article: \\ Monteiro R, Hallikeri K, Sudhakaran A. \\ PTEN and $\alpha$-SMA Expression and Diagnostic Role in Oral Submucous Fibrosis and Oral Squamous Cell Carcinoma with \\ Concomitant Oral Submucous Fibrosis \\ J Oral Maxillofac Res 2021;12(1):e3 \\ URL: http://www.ejomr.org/JOMR/archives/2021/1/e3/v12n1e3.pdf \\ doi: $10.5037 /$ jomr.2021.12103
}




\section{INTRODUCTION}

Oral potentially malignant disorders (OPMDs) are precursors of oral squamous cell carcinoma (OSCC). Thus prevention and early detection of OPMDs aids in decreasing the incidence and improves survival of those who could develop OSCC. Oral submucous fibrosis (OSF), a PMD has high prevalence in Indian subcontinent and South East Asia and is associated with chewing betel quid and commercially available areca nut preparations [1]. OSF is a chronic, insidious oral mucosal condition, characterized by juxtaepithelial inflammation and submucosal fibrosis induced by alkaloids (arecoline, arecaidine, guvacaine, guvacoline) and flavonoids in areca nut [2]. The younger population is mainly affected. A high malignant transformation rate ranging from 7 to $13 \%$, and in India, ranging from 2.6 to $7.6 \%$ has been reported [1].

Tremendous efforts have been made to identify predictable diagnostic biomarkers like p53, $\beta$ catenin, cyclin D1, Rb protein, Ki67 (MIB), bc12, bax, c-met, alpha-smooth muscle actin ( $\alpha$-SMA), phosphatase and tensin homologue (PTEN), in OSF and their role in malignant transformation [3-5].

PTEN acts as a tumour suppressor gene and controller of myofibroblast differentiation by negatively regulating phosphatidyl inositol-3-kinase/AKT (PI3K/ AKT) pathway in fibrotic disorders and malignancies of thyroid, kidney, lung, breast; endometrial precancer and also plays a role in immunity [6-11]. In OSF, like other fibrotic lesions, myofibroblasts express $\alpha$-SMA and are the primary producers of extracellular matrix (ECM) $[\underline{12}, \underline{13}]$. An inverse correlation between PTEN and $\alpha$-SMA expression has been noted in dermal fibrosis, idiopathic pulmonary fibrosis (IPF) and hepatic fibrosis [6,14-16].

The mechanism by which PTEN controls myofibroblast expression and the diagnostic role of PTEN and $\alpha$-SMA in malignant transformation of OSF has not yet been studied. A better understanding of the relation between PTEN and $\alpha$-SMA may help in unveiling their diagnostic and prognostic role in OSF and OSCC. Also the drugs targeting PI3K might have significant therapeutic activity in OSF and its malignant transformation. The presented retrospective case control study aimed at evaluating the phosphatase and tensin homologue mechanism controlling myofibroblast expression. Also analysed the diagnostic role and correlation between phosphatase and tensin homologue and alpha-smooth muscle actin in oral submucous fibrosis and oral squamous cell carcinoma with concomitant oral submucous fibrosis.

\section{MATERIAL AND METHODS}

The case control study was approved by the Institutional Review Board (IRB NO. IRB/2017/P/ $\mathrm{OP} / 55)$ of SDM College of Dental Sciences and Hospital, Dharwad, Karnataka, India. Following the approval, 70 formalin-fixed paraffin-embedded tissue blocks of OSF and OSCC with concomitant OSF having complete case details were selected randomly and retrieved from the archives of the Department of Oral Pathology and Microbiology, SDM College of Dental Sciences and Hospital. The study was conducted between January 2018 to June 2019.

The sample comprising of 70 cases was divided into three groups. The control group had 10 normal mucosa tissues from patients with no relevant habit history, with a healthy mucosa and without any systemic diseases or malignancies. The other two groups had 30 cases each of clinically and histologically (stained with haematoxylin and eosin) proven OSF and OSCC with concomitant OSF respectively. Clinical staging of OSF cases was done based on mouth opening according to Ranganathan et al. [17] and TNM staging was followed for OSCC with concomitant OSF [18]. Histopathologically, OSF was subdivided according to Roobans' grading [19] and OSCC with concomitant OSF using Broders' grading [20]. Patients with recurrence and those under treatment for oral carcinoma were excluded. The clinicopathological data of all cases were recorded and tabulated.

Tissue sections of $3 \mu \mathrm{m}$ obtained from all cases on silane coated slides were subjected to immunohistochemical (IHC) analysis using PTEN protein rabbit monoclonal antibody (clone SP218, IgG immunoglobulin) and $\alpha$-SMA mouse monoclonal antibody (clone 1A4, IgG2a immunoglobulin), and visualized by supersensitive polymer-HRP detection system (BioGenex Laboratories Inc.; San Ramon, California, USA); chromogen used was DAB (diaminobenzidine). Antigen heat retrieval was done using pressure cooker $(0.1 \mathrm{M}$ citrate buffer; $\mathrm{pH}$ 6). Standardized procedure according to the guidelines given by BioGenex Laboratories Inc. was followed. Brown precipitate in the nucleus and cytoplasm was considered to be a positive PTEN and $\alpha$-SMA expression respectively.

The sections were examined at an ocular magnification of $\times 10$ and then a representative field (even staining) was chosen viewing at original magnification $\mathrm{x} 40$. Positive cells were counted from among 500 total tumour cells.

The following parameters were analysed: 
- Percentage of positive cells: $0=$ no positive cells, $1=1$ to $25 \%, 2=26$ to $50 \%, 3=>50 \%$.

- Pattern of expression: $0=$ absent, $1=$ membrane, 2 = cytoplasm, 3 = membrane and cytoplasm, $4=$ nuclear.

- Expression in layers of mucosa: $0=$ absent, $1=$ basal $/$ parabasal, $2=$ spinous, $3=$ superficial layer.

\section{Statistical analysis}

Non-parametric statistical analysis was done depending on the results by means of SPSS Statistics software, version 20.0 (IBM; New York, USA). Pearson's Chi-square and Fischer exact tests were used to analyse the correlation between the clinicopathological parameters, compare the IHC expression of PTEN and $\alpha$-SMA and to correlate the expression with the clinicopathological parameters. Statistical significance level was defined at $\mathrm{P}<0.05$. Spearman correlation was used to find the correlation between the two markers.

\section{RESULTS}

The clinicopathological parameters of the study groups were assessed. Greater number of patients were below
40 years of age in OSF (73.3\%), in contrast $63.3 \%$ cases of OSCC, were above the age of 40 years $(\mathrm{P}=0.005)$. OSF group had all male patients $(100 \%)$ and a male predilection was seen in OSCC $(90 \%)$.

Chewing smokeless tobacco for more than 5 years was more prevalent among the groups $(\mathrm{OSF}=93.3 \%$ and OSCC $=86.65 \%$ ) than smoking.

Predominant site of involvement for OSCC was buccal mucosa $(63.3 \%)$ followed by other sites- lip, alveolus $(33.3 \%)$; tongue being the least affected (3.3\%) $(\mathrm{P}<0.001)$.

In OSF, stage I and II were combined (26.6\% cases), stage III and IV were combined $(73.3 \%$ cases). Similarly, in OSCC, stage I and II were combined ( $90 \%$ cases), stage III and IV were combined $(10 \%$ cases) $(\mathrm{P}<0.001)$.

Roobans histopathological grading of OSF showed most cases in the combined grade I and II $(73.3 \%)$ followed by the combined grade III and IV (26.6\%). The well and moderately differentiated OSCC had $76.6 \%$ and $23.3 \%$ cases respectively $(\mathrm{P}=0.003)$.

In OSCC, depth of invasion (DOI) of tumour was grouped as $<5 \mathrm{~mm}(30 \%), 5$ to $10 \mathrm{~mm}(40 \%)$ and $>10$ $\mathrm{mm}(30 \%)$. Lymph node positivity was seen in $36.6 \%$ cases.

Statistical significant difference in the age, site, staging and grading among the study groups existed (Table 1).

Table 1. Clinicopathological data of groups using Pearson's Chi-square and Fisher exact test

\begin{tabular}{|c|c|c|c|c|c|}
\hline \multirow{2}{*}{ Parameters } & \multirow{2}{*}{ Category } & NM-10 & OSF-30 & OSCC + OSF-30 & \multirow{2}{*}{ P-value } \\
\hline & & $\mathrm{N}(\%)$ & N (\%) & $\mathbf{N}(\%)$ & \\
\hline \multirow{2}{*}{$\begin{array}{c}\text { Age } \\
\text { (years) }\end{array}$} & $<40$ & $8(80)$ & $22(73.3)$ & $11(36.6)$ & \multirow{2}{*}{$0.005^{b}$} \\
\hline & $\geq 40$ & $2(20)$ & $8(26.6)$ & $19(63.3)$ & \\
\hline \multirow{2}{*}{ Sex } & Male & $8(80)$ & $30(100)$ & $27(90)$ & \multirow[b]{2}{*}{0.72} \\
\hline & Female & $2(20)$ & 0 & $3(10)$ & \\
\hline \multirow{2}{*}{ Habits } & Chewing & - & $28(93.3)$ & $26(86.6)$ & \multirow{2}{*}{0.548} \\
\hline & Mixed & - & $2(6.7)$ & $2(6.6)$ & \\
\hline \multirow{2}{*}{ Frequency } & $<5$ times & - & $17(56.6)$ & $20(66.6)$ & \multirow{2}{*}{0.426} \\
\hline & $\geq 5$ times & - & $13(43.3)$ & $10(33.3)$ & \\
\hline \multirow{2}{*}{ Duration } & $<5$ years & - & $14(46.6)$ & $11(36.6)$ & \multirow{2}{*}{0.432} \\
\hline & $\geq 5$ years & - & $16(53.3)$ & $19(63.3)$ & \\
\hline \multirow{2}{*}{ Site } & Buccal mucosa & - & - & $19(63.3)$ & \multirow{2}{*}{$<0.001^{\mathrm{b}}$} \\
\hline & Others & - & - & $10(33.3)$ & \\
\hline \multirow{2}{*}{ OSF staging } & Stage I and II & - & $9(30)$ & - & \multirow{2}{*}{0.11} \\
\hline & Stage III and IV & - & $21(70)$ & - & \\
\hline \multirow{2}{*}{ OSF grading } & Stage I and II & - & $22(73.3)$ & - & \multirow{2}{*}{$<0.001^{\mathrm{b}}$} \\
\hline & Stage III and IV & - & $8(26.6)$ & - & \\
\hline \multirow{2}{*}{ OSCC staging } & Stage I and II & - & - & $27(90)$ & \multirow{2}{*}{$0.028^{\mathrm{a}}$} \\
\hline & Stage III and IV & - & - & $3(10)$ & \\
\hline \multirow{2}{*}{ OSCC grading } & Well diff & - & - & $23(76.6)$ & \multirow{2}{*}{$0.003^{b}$} \\
\hline & Moderately diff & - & - & $7(23.3)$ & \\
\hline \multirow{3}{*}{ DOI } & $<5 \mathrm{~mm}$ & - & - & $9(30)$ & \multirow{3}{*}{0.741} \\
\hline & 5 to $10 \mathrm{~mm}$ & - & - & $12(40)$ & \\
\hline & $>10 \mathrm{~mm}$ & - & - & $9(30)$ & \\
\hline \multirow{2}{*}{ Lymph node } & Positive & - & - & $11(36.6)$ & \multirow{2}{*}{0.144} \\
\hline & Negative & - & - & $19(63.3)$ & \\
\hline
\end{tabular}

${ }^{a}$ Statistically significant at level $\mathrm{P}<0.05$, Pearson's Chi-square and at level $\mathrm{P}<0.05$, Fischer exact test. ${ }^{\mathrm{b}}$ Statistically highly significant at level $\mathrm{P}<0.05$, Pearson's Chi-square and at level $\mathrm{P}<0.05$, Fischer exact test. $\mathrm{NM}=$ normal mucosa; OSF $=$ oral submucous fibrosis; $\mathrm{OSCC}=$ oral squamous cell carcinoma; $\mathrm{N}=$ number . 
Percentage of PTEN positive cells was statistically significant with gender $(\mathrm{P}=0.024)$ and $\alpha$-SMA distribution of pattern showed a significant correlation with habits $(\mathrm{P}=0.018)$. A significant decrease in nuclear PTEN positivity $(\mathrm{P}<0.001)$ and gradual increase in $\alpha$-SMA cytoplasmic expression was noted from normal mucosa to OSF and OSCC. A statistically significant weak inverse correlation existed between PTEN and $\alpha$-SMA.

PTEN nuclear expression was seen in basal and parabasal layers of normal and OSF epithelium (Figure 1) and in OSCC, in the peripheral cells of tumour islands (Figure 2) $(\mathrm{P}=0.233)$. In the normal mucosa, 1 to $25 \%$ positive cells were seen in $40 \%$ and 26 to $50 \%$ in $50 \%$ of tissues, while in OSF, $66.6 \%$ and in OSCC,
$30 \%$ had 1 to $25 \%$ positive cells $(\mathrm{P}<0.001)$. Thus a reduction in the expression was noted i.e., 33.3\% OSF cases and $70 \%$ OSCC cases failed to show any expression. This difference was statistically significant $(\mathrm{P}=0.001)($ Table 2).

In case of $\alpha$-SMA, cytoplasmic positivity was seen in $30 \%$ of NM, $53.3 \%$ of OSF (Figure 3 ) and $56.6 \%$ of OSCC (Figure 4). There was no statistically significant difference among the study groups.

Comparison of percentage of positive cells of PTEN with the clinicopathological parameters showed a statistical significant difference for gender $(\mathrm{P}=0.024)$. Distribution of pattern of PTEN showed no statistically significant difference for any of the clinicopathological parameters (Table 3).

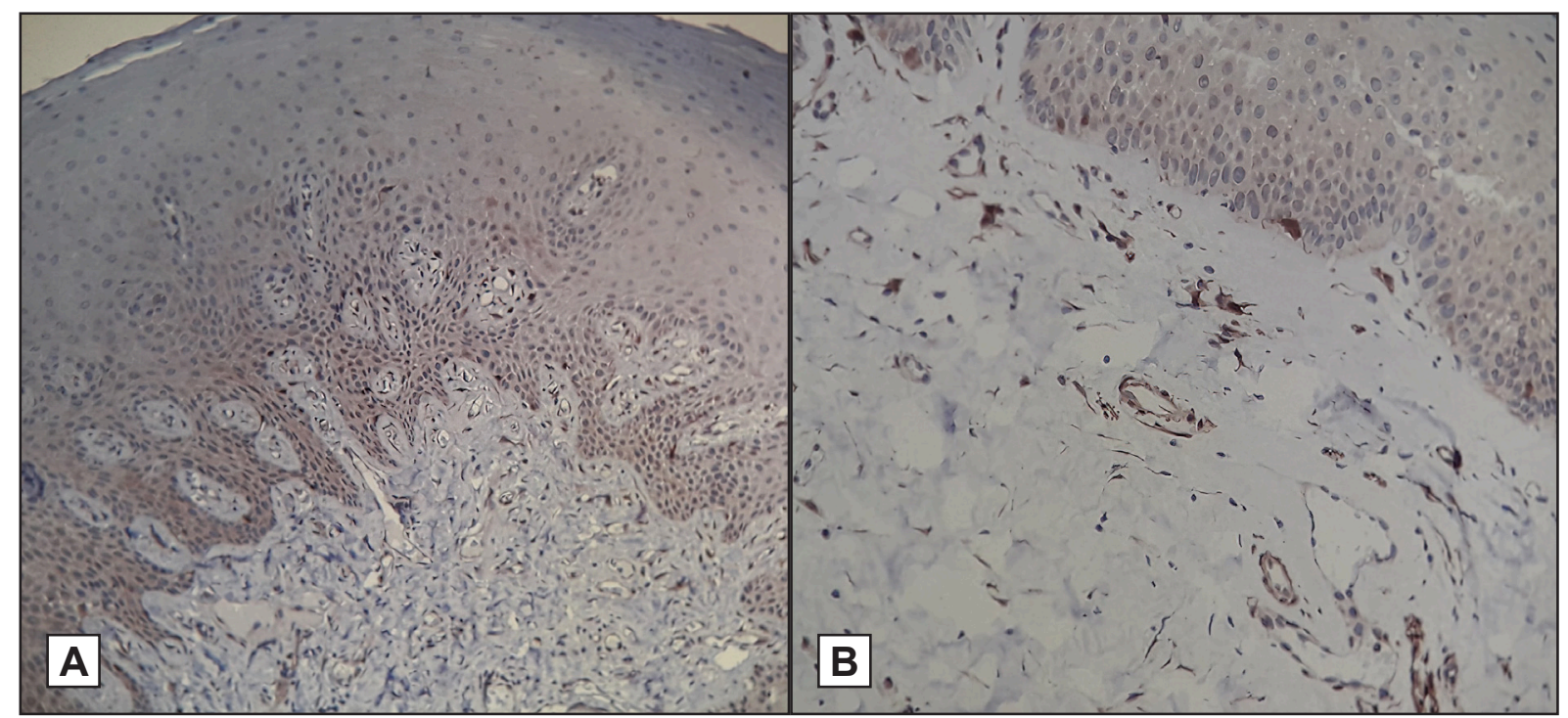

Figure 1. Nuclear phosphatase and tensin homologue staining in basal and parabasal layers.

$\mathrm{A}=$ normal mucosa (original magnification $\mathrm{x} 20$ ). $\mathrm{B}=$ oral submucous fibrosis (original magnification $\mathrm{x} 40$ ).

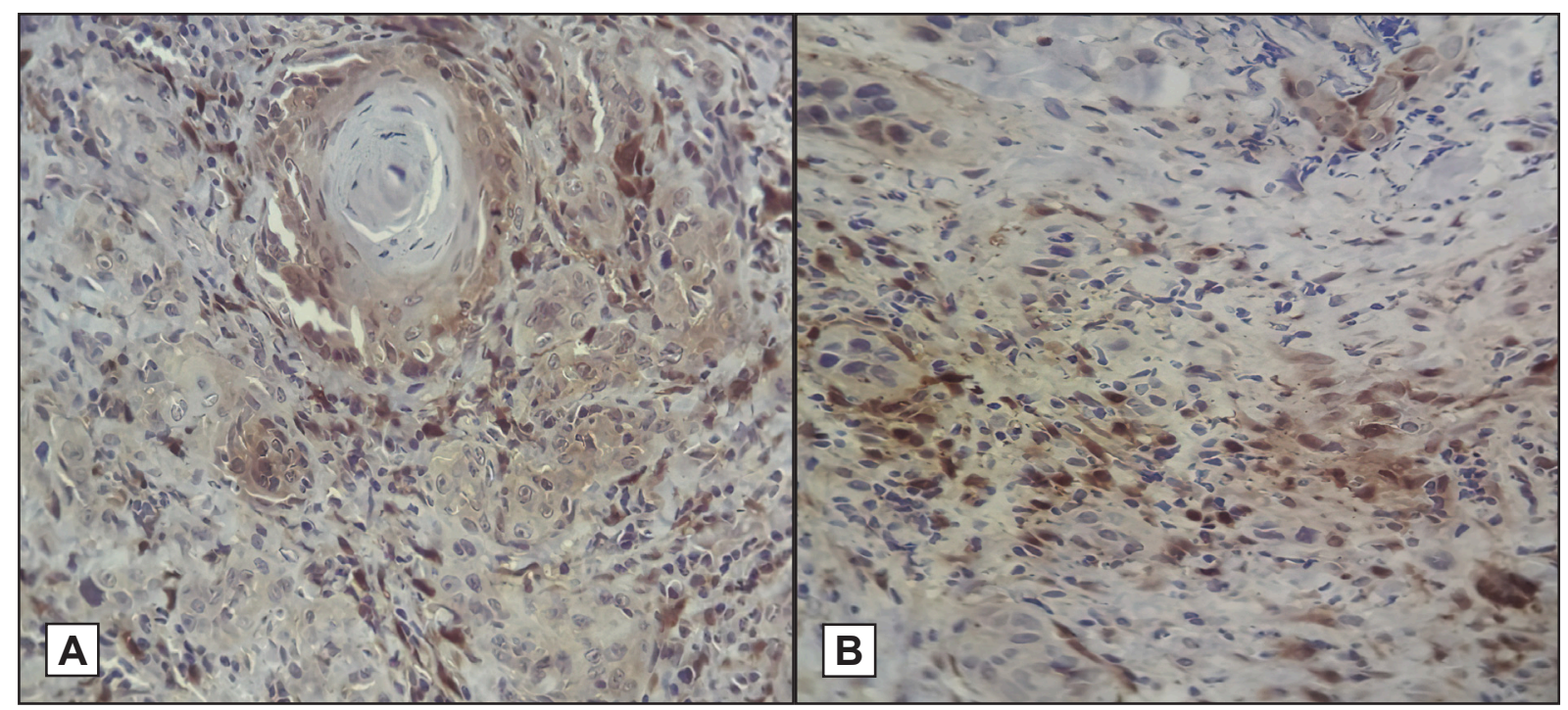

Figure 2. Phosphatase and tensin homologue (PTEN) nuclear staining.

$\mathrm{A}=$ Intense PTEN staining in tumour islands of oral squamous cell carcinoma (OSCC) with concomitant oral submucous fibrosis (OSF) (original magnification x20). B = Intense nuclear PTEN staining in tumour cells of OSCC with concomitant OSF (original magnification $\mathrm{x} 40$ ). 
Table 2. Comparison of IHC expression of PTEN among groups using Pearson's Chi-square and Fisher exact test

\begin{tabular}{|c|c|c|c|c|c|}
\hline \multirow{2}{*}{ Parameters } & \multirow{2}{*}{ Category } & NM & OSF & OSF + OSCC & \multirow{2}{*}{ P-value } \\
\hline & & $\mathbf{N}(\%)$ & $\mathbf{N}(\%)$ & $\mathbf{N}(\%)$ & \\
\hline \multirow{4}{*}{$\begin{array}{l}\text { Percentage } \\
\text { positivity }\end{array}$} & $0=$ no positive cells & $1(10)$ & $10(33.3)$ & $21(70)$ & \multirow{4}{*}{$<0.001^{\mathrm{a}}$} \\
\hline & $1=0$ to $25 \%$ & $4(40)$ & $20(66.6)$ & $9(30)$ & \\
\hline & $2=26$ to $50 \%$ & $5(50)$ & - & - & \\
\hline & $3=>50 \%$ & - & - & - & \\
\hline \multirow{3}{*}{ Pattern } & Absent & $1(10)$ & $10(33.3)$ & $21(70)$ & \multirow{3}{*}{$0.001^{\mathrm{a}}$} \\
\hline & Cytoplasm & - & - & - & \\
\hline & Nuclear & $9(90)$ & $20(66.6)$ & $9(30)$ & \\
\hline \multirow{4}{*}{ Layers } & $0=\mathrm{absent}$ & $1(10)$ & $10(33.3)$ & - & \multirow{4}{*}{0.233} \\
\hline & $1=$ basal/parabasal & $9(90)$ & $20(66.6)$ & - & \\
\hline & $2=$ spinous & - & - & - & \\
\hline & $3=$ superficial layer & - & - & - & \\
\hline
\end{tabular}

a'Statistically significant at level $\mathrm{P}<0.05$, Pearson's Chi-square and at level $\mathrm{P}<0.05$, Fischer exact test. $\mathrm{NM}=$ normal mucosa; $\mathrm{OSF}=$ oral submucous fibrosis; OSCC $=$ oral squamous cell carcinoma; $\mathrm{N}=$ number; $\mathrm{IHC}=$ immunohistochemical; PTEN = phosphatase and tensin homologue.

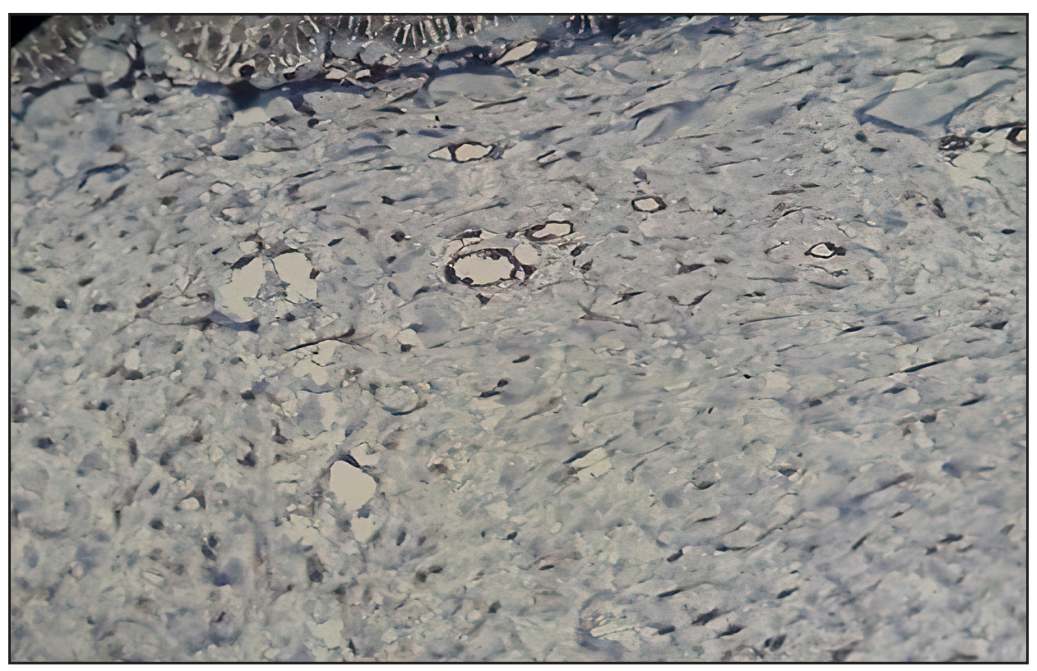

Figure 3. Alpha-smooth muscle actin staining around the vessel walls taken as internal control and in the myofibroblast cytoplasm in the connective tissue stroma of oral submucous fibrosis (original magnification $\mathrm{x} 40$ ).

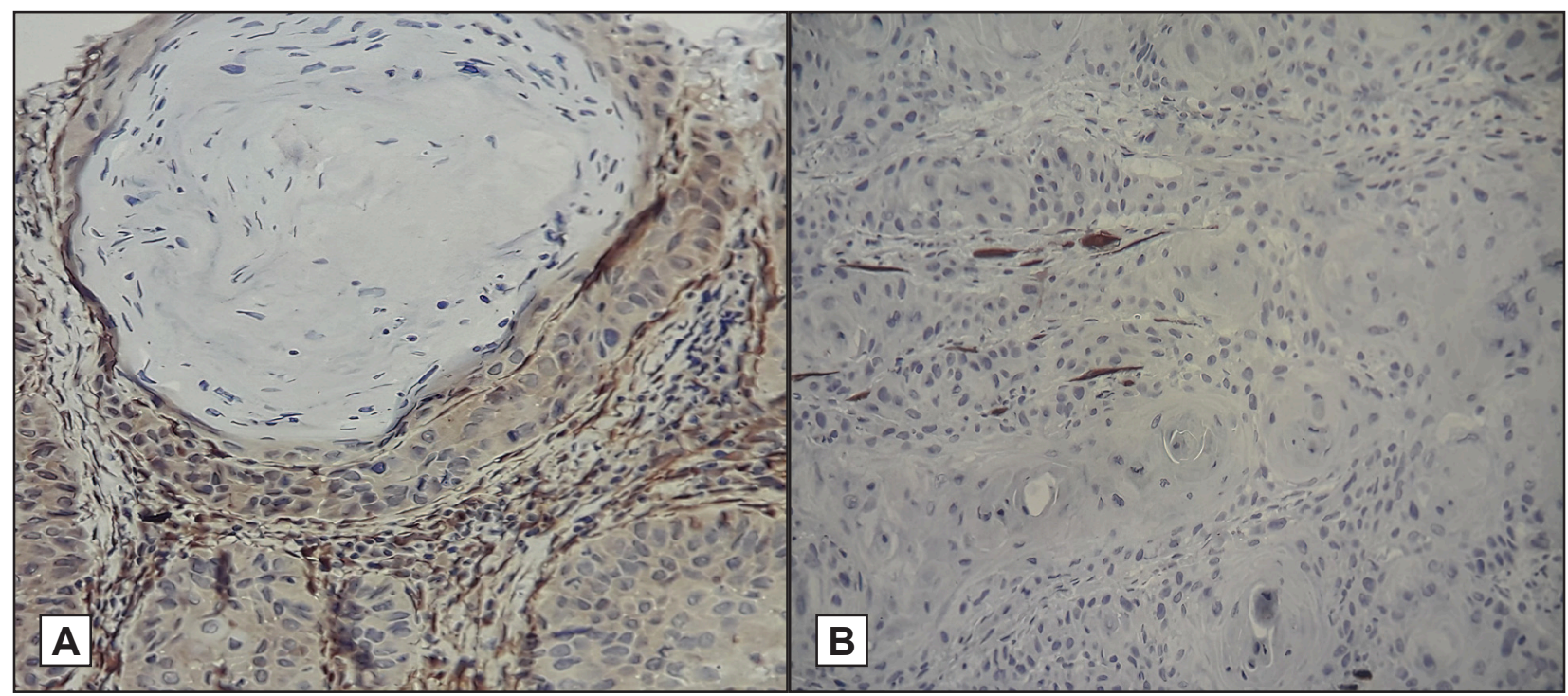

Figure 4. Cytoplasmic alpha-smooth muscle actin staining myofibroblasts in the connective tissue stroma of oral squamous cell carcinoma: $\mathrm{A}=$ original magnification $\mathrm{x} 20 ; \mathrm{B}=$ original magnification $\mathrm{x} 40$. 
Table 3. Comparison of IHC expression of $\alpha$-SMA among groups using Pearson Chi-square and Fisher exact test

\begin{tabular}{|c|c|c|c|c|c|}
\hline \multirow{2}{*}{ Parameters } & \multirow{2}{*}{ Category } & NM & OSF & OSF + OSCC & \multirow{2}{*}{ P-value } \\
\hline & & N (\%) & N (\%) & N (\%) & \\
\hline \multirow{4}{*}{$\begin{array}{l}\text { Percentage } \\
\text { positivity }\end{array}$} & $0=$ no positive cells & $7(70)$ & $14(46.6)$ & $13(43.3)$ & \multirow{4}{*}{0.426} \\
\hline & $1=0$ to $25 \%$ & $3(30)$ & $16(53.3)$ & $15(50)$ & \\
\hline & $2=26$ to $50 \%$ & - & - & $2(6.6)$ & \\
\hline & $3=>50 \%$ & - & - & - & \\
\hline \multirow{3}{*}{ Pattern } & Absent & $7(70)$ & $14(46.6)$ & $13(43.3)$ & \multirow{3}{*}{0.331} \\
\hline & Cytoplasm & $3(30)$ & $16(53.3)$ & $17(56.6)$ & \\
\hline & Nuclear & - & - & - & \\
\hline
\end{tabular}

$\mathrm{NM}=$ normal mucosa; $\mathrm{OSF}=$ oral submucous fibrosis; $\mathrm{OSCC}=$ oral squamous cell carcinoma; $\mathrm{N}=$ number; $\mathrm{IHC}=$ immunohistochemical; $\alpha-\mathrm{SMA}=$ alpha- smooth muscle actin.

Percentage positivity of $\alpha$-SMA showed no statistically significant difference for clinicopathological parameters, but distribution of pattern of $\alpha$-SMA showed a significant correlation with habits.

Comparison of percentage positivity of PTEN and $\alpha$-SMA showed no statistical significant difference in OSF and OSCC groups, while the distribution of pattern of PTEN and $\alpha$-SMA had a high statistical significant difference in all three study groups $(\mathrm{P}<0.001)$ (Figure 5).

Spearman correlation between PTEN and $\alpha$-SMA among study groups showed a statistically significant weak inverse correlation $(\mathrm{P}=0.012)$

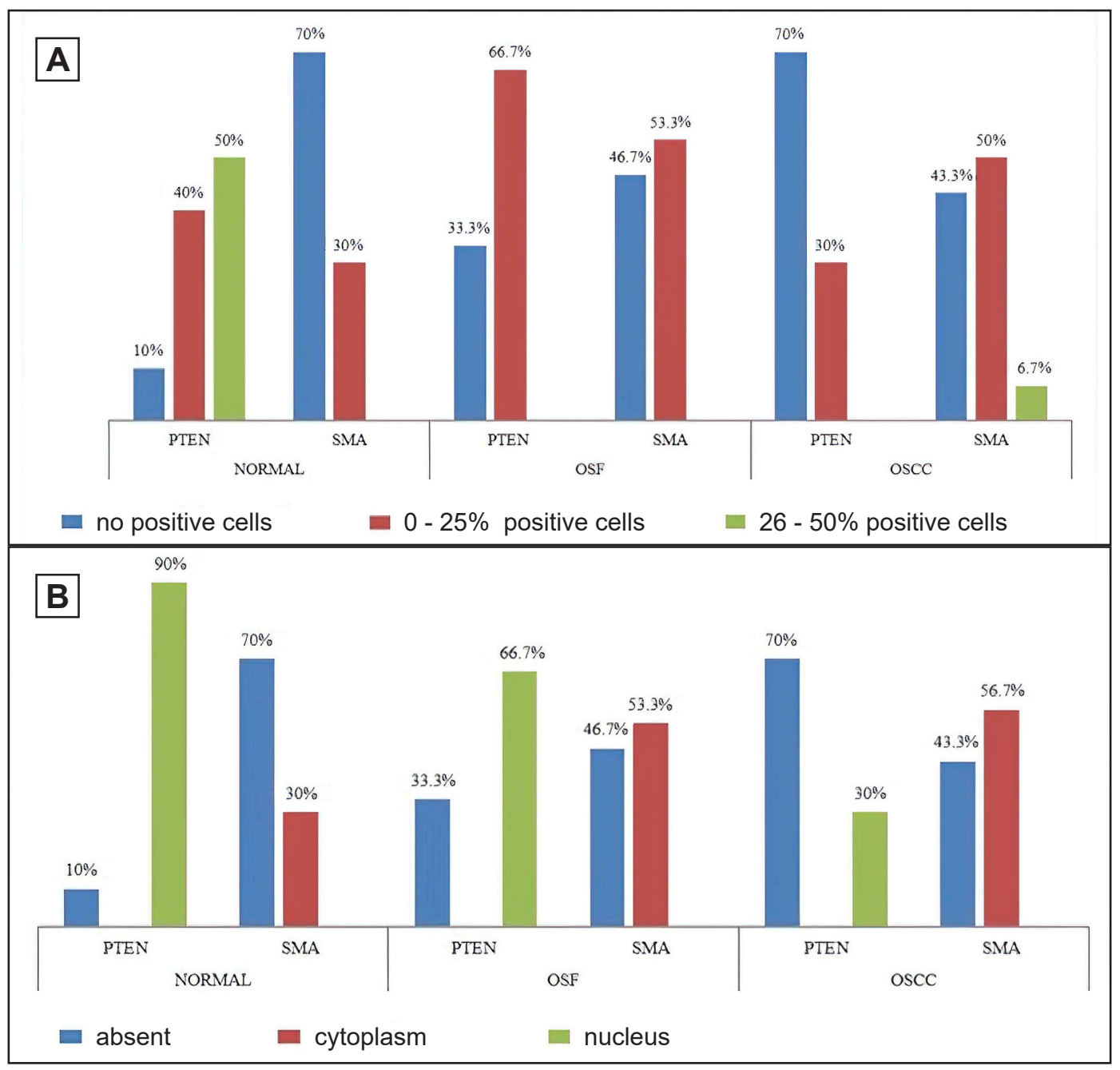

Figure 5. A = comparison of percentage positivity of phosphatase and tensin homologue and alpha-smooth muscle actin. $\mathrm{B}=$ comparison of distribution of pattern of phosphatase and tensin homologue and alpha-smooth muscle actin. 


\section{DISCUSSION}

PTEN, on chromosome 10q23 is "the most highly mutated gene in the post p53 era", encoding a protein which dephosphorylates both protein and lipid substrates and negatively regulates the PI3K/AKT pathway [21-23]. Normally, the lipid phosphatase dephosphorylates PIP3, opposing PI3K and inhibits activation of the downstream pathway [24]. The dephosphorylation inactivates substrates making it a tumour suppressor gene. PTEN inactivation leads to PI3K/AKT activation and phosphorylation of PIP2 in the 3' position of the inositol ring at the cell membrane leading to PIP3 synthesis and initiation of G1 phase of cell cycle and reduction in apoptosis, thereby predisposing to the development of cancer $[21,22]$. PTEN has been studied in precancers of endometrium, leukoplakia; cancers of breast, prostate, endometrium and head and neck $[\underline{9}, 21,22,25]$. PTEN also negatively regulates cell survival and fibroblast proliferation in the pathogenesis of fibrotic disorders like OSF, lung fibrosis, dermal fibrosis, hepatic fibrosis $[\underline{6}, \underline{14}, 15,21]$.

The clinicopathological parameters in relation to OSF in the present study were in accordance with that of previous studies where predominantly males in the second and third decades of life with the habit of chewing ghutka and other commercially available areca nut preparations for more than 10 years were affected by OSF; with the severity related to frequency and duration of habit $[\underline{26}, \underline{27}]$. OSCC concomitant with OSF, in contrast to our study has been reported to affect males below 50 years of age while OSCC without OSF in patients above 50 years of age, probably because patients suffering from OSCC without concomitant OSF do not normally experience pain and discomfort till the lesion progresses to a functionally restrictive stage [28-30]. Likewise, males with the habit of consuming commercially available areca nut preparations for more than 5 years have been reported to be at higher risk of OSCC with OSF $[29,30]$. In OSCC with OSF, the fibrous stroma limiting tumour infiltration, accounts for better prognosis than in OSCC without OSF by means of tumour depth and differentiation. Also lymph node metastasis and extracapsular spread (ECS) is less in OSCC arising from OSF $[\underline{29}, \underline{30}]$. However, controversy still exists regarding the prognosis of OSCC with and without OSF.

Apart from the clinicopathological aspect, oral carcinogenesis encompasses mutations and epigenetic abnormalities in the activation of oncogenes and inactivation of tumour suppressor genes that control cell growth, inhibit cell proliferation by inducing apoptosis and tumour development [31]. With this background, we undertook this study to know more about the molecular changes in the malignant transformation of OSF. Tumour suppressor genes $\mathrm{p} 53$, p16, retinoblastoma (RB), PTEN have been studied in OSF to assess their role in progression of cancer and prediction of malignant transformation $[\underline{32}, \underline{33}]$. Likewise, we studied the expression of PTEN in normal mucosa, OSF and OSCC with concomitant OSF.

An intense nuclear PTEN staining seen in basal and parabasal layers in nearly all normal and OSF epithelium pointed out its normal function, but the percentage of positivity gradually reduced in OSF group, probably indicating the $33.3 \%$ OSF cases with loss of expression are more prone to malignant transformation. This was substantiated by the OSCC group exhibiting a further gradual decrease in the number of positive cells (i.e., 70\% were negative), seen at the periphery of tumour islands. Angadi and Krishnapillai [21], have also reported an intense nuclear stain in basal and parabasal layers of normal and OSF epithelium that reduced progressively from OSF to OSCC with positive cells at the tumour island periphery. Nuclear PTEN maintains chromosomal stability through physical interaction with centromeres and control of DNA repair [34]. Contrastingly, Jasphin et al. [35] on assessing the expression of PTEN between grades of OSCC, noted positivity in the cell cytoplasm; predominantly in basal and spinous layers with intensity reducing towards the granular layer. However, in spite of a decrease in the cells staining for PTEN in OSCC compared to the normal tissues, no statistical significance was seen in expression among the grades.

While nuclear PTEN is more stable and retains the capability of inhibiting AKT and inducing cell death, it downregulates cyclin D1 and phospho-MAPK and is thus crucial for cell cycle arrest $[\underline{36}, \underline{37}]$. Compared to cytoplasmic staining, nuclear staining of PTEN is more marked particularly in undifferentiated and metastatic tumours of thyroid and melanoma. But the role of this shift in cellular localization in tumour pathogenesis is yet to be understood [38].

An increase in PTEN expression predominantly in basal and parabasal cell cytoplasm in dysplasia may be considered an attempt to control the increased AKT expression. In leukoplakia, PTEN allelic loss is an important mechanism causing progression to oral cancer [25].

The expression and genetic alterations of PTEN in OSCC have shown the epigenetic changes to be related to a down regulation of the protein [39]. 
The homozygous deletion or point mutation may not play a crucial role in PTEN inactivation process of carcinomas of oral cavity [40]. Activation of AKT is known to be associated with advanced stages and poor prognosis in OSCC; and induced PTEN overexpression downregulates AKT phosphorylation and encourages apoptosis [35].

In malignancies of human brain, breast and prostate, PTEN mutations have been assessed [8]. Squarize et al. [24], found multiple HNSCC lesions in PTEN deficient mice. Mutter et al. [9], reported PTEN mutations in $83 \%$ of endometrial cancers and $55 \%$ of precancers; most had mutation in only one PTEN allele. Roa et al. [22], noted that patients with reduced PTEN expression died within 10 months indicating poor prognosis.

Functionally, PTEN controls/regulates p53 by preventing its degradation through PI3K signalling pathway [41,42]. Inactivation of PI3K pathway, leads to decreased phosphorylation of mouse double minute 2 homolog (MDM2) by AKT and translocation of MDM2 to cytoplasm. Cytoplasmic MDM2 cannot ubiquitinate nuclear p53 and so p53 levels increase. Thus p53 increases PTEN levels and, conversely, PTEN increases p53 levels $[\underline{8}, \underline{43}]$. Studies in mammary tumours and liposarcomas showed that p53 combined with PTEN might be an essential blockage in their development $[\underline{44}, \underline{45}]$.

In consort with tumour suppressor genes, the stroma comprising inflammatory cells, small vessels, fibroblasts, myofibroblasts, and ECM components is vital in controlling tumour growth and differentiation. Myofibroblasts, the key cellular mediators of fibrosis in OSF express $\alpha$-SMA, produce collagen, ECM proteins and proteolytic enzymes causing matrix degradation and tumour invasion $[\underline{12}, \underline{46}, \underline{47}]$. PTEN playing a role in embryogenesis, immunity, fibrosis and malignancy is known to have an inverse correlation with $\alpha$-SMA $[\underline{11}, \underline{48}, \underline{49}]$. Thus PTEN acts both as a tumour suppressor and controller of myofibroblast.

PTEN gene inactivation results in TGF $\beta 1$ induced disassembly of tight junction of epithelial cells, destruction of basement membrane and increased epithelial derived myofibroblast due to up-regulation of AKT/S6K/Snail pathway, playing a role in epithelial-mesenchymal transition (EMT) [14].

According to Xie et al. [50], PTEN overexpression decreases signalling via the PI3K/AKT and TGF $\beta /$ Smad3 pathways in IPF and inhibits TGF $\beta 1$ mediated myofibroblast differentiation. An increased TGF $\beta$ in OSF can reduce PTEN levels allowing for AKT activity and consequently prolonged survival of fibroblasts and increased ECM production and fibrosis [21]. Deletion of PTEN in mouse fibroblasts raises AKT phosphorylation and expression of connective tissue growth factor $(\mathrm{CTGF} / \mathrm{CCN} 2)$ and an escalation in dermal thickness owing to excess collagen deposition. An elevated selective inhibition of PI3K/AKT pathway reduces overexpression of collagen and CCN2. Thus, PTEN appears to be a potential regulator of fibrogenesis [6].

In the present study, an intense $\alpha$-SMA staining in myofibroblast cytoplasm, relatively more in OSF and OSCC than in normal mucosa with gradual increase both from normal to OSF and OSF to OSCC was witnessed. But a statistical significance difference failed to exist. In OSF group, 12 cases were in the combined stage I and II, 4 were in the combined stage III and IV. Similar observations with an increase in number of $\alpha$-SMA stained myofibroblasts in OSF compared to normal mucosa, but with a statistically significant increase in population between early and advanced stages have been reported, demonstrating that myofibroblasts could serve as effective prognostic markers for disease progression in OSF $[\underline{12}, \underline{13}, \underline{51}, \underline{52}]$. Alka et al. [51], revealed high $\alpha$-SMA expression in OSCC with and without OSF compared to OSF, which indicated despite the statistically insignificant difference, altered ECM in OSCC with OSF may perhaps be responsible for modified EMT. In OSCC not associated with OSF, expression of $\alpha$-SMA is greater in OSCC than in OSF alone or OSF associated with dysplasia. The proteolytic enzymes secreted by activated myofibroblasts cause matrix degradation, contributing to cancer cell invasion and metastasis $[\underline{12}, \underline{16}]$. In OSCC arising from OSF, EMT occurs first when areca nut induced cell injury causes excessive collagen cross-linking in ECM; second when there is malignant transformation during which cytokines and growth factors released from cancer cells induce myofibroblast transdifferentiation [53].

A positive correlation between OSCC histological grades and myofibroblasts has not been established, suggesting formation and differentiation of myofibroblasts is induced somewhere in the invasive stage of OSCC, and an increase in severity and differentiation would not affect their number $[54,55]$. Also variation in TGF $\beta$ secretion essential for myofibroblast differentiation by tumour cells could be a reason for the decrease in myofibroblasts [51].

We noted a gradual decrease in PTEN expression and a gradual increase in $\alpha$-SMA expression from normal to OSF and OSCC, providing a weak inverse correlation between PTEN and $\alpha$-SMA. In IPF, an inverse correlation between PTEN and $\alpha$-SMA expression has been established and $\alpha$-SMA is the hallmark of mature myofibroblasts $[\underline{56}, \underline{57}]$. 
Once fibrosis is established, there can be either persistence without significant progression of disease or eventual malignant transformation [52]. An increase in number of myofibroblast both in OSCC associated and not associated with OSF indicates a poor prognosis $[19,21]$. Thus PTEN controlling fibroblast differentiation into myofibroblast plays a definite role in carcinogenesis. However, the present study suffered from certain shortcomings. A larger sample size and a follow-up of the cases would certainly aid in knowing the response to the treatment and a better validation of the results.

\section{CONCLUSIONS}

The presented study concludes the absence of phosphatase and tensin homologue positivity in oral submucous fibrosis suggests these cases have a greater tendency to progress towards malignancy. Thus phosphatase and tensin homologue plays a crucial role in tumorigenesis of oral squamous cell carcinoma. In addition, alpha-smooth muscle actin has an effective prognostic role in disease progression of oral submucous fibrosis.

The weak inverse correlation between phosphatase and tensin homologue and alpha-smooth muscle actin showed that phosphatase and tensin homologue aids in myofibroblast differentiation in oral submucous fibrosis, further increasing fibrosis and desmoplasia. Thus alteration of phosphatase and tensin homologue and alpha-smooth muscle actin is likely an important molecular event in pathogenesis of oral submucous fibrosis and its malignant transformation. Since phosphatase and tensin homologue is involved in the PI3K/AKT pathway, drugs targeting PI3K itself might have significant therapeutic activity in phosphatase and tensin homologue null cancers.

\section{ACKNOWLEDGMENTS AND DISCLOSURE STATEMENTS}

The authors report no conflicts of interest related to this study.

\section{REFERENCES}

1. Ray JG, Ranganathan K, Chattopadhyay A. Malignant transformation of oral submucous fibrosis: overview of histopathological aspects. Oral Surg Oral Med Oral Pathol Oral Radiol. 2016 Aug;122(2):200-9. [Medline: 27422418] [doi: 10.1016/j.0000.2015.11.024]

2. Angadi PV, Rao SS. Areca nut in pathogenesis of oral submucous fibrosis: revisited. Oral Maxillofac Surg. 2011 Mar;15(1):1-9. [Medline: 20376683] [doi: 10.1007/s10006-010-0219-8]

3. Bazarsad S, Zhang X, Kim KY, Illeperuma R, Jayasinghe RD, Tilakaratne WM, Kim J. Identification of a combined biomarker for malignant transformation in oral submucous fibrosis. J Oral Pathol Med. 2017 Jul;46(6):431-438. [Medline: 27497264] [PMC free article: 5516200] [doi: 10.1111/jop.12483]

4. Ranganathan K, Kavitha R. Proliferation and apoptosis markers in oral submucous fibrosis. J Oral Maxillofac Pathol. 2011 May;15(2):148-53. [Medline: 22529572] [PMC free article: 3329703] [doi: 10.4103/0973-029X.84478]

5. Seifi S, Shafaei S, Shafigh E, Sahabi SM, Ghasemi H. Myofibroblast stromal presence and distribution in squamous epithelial carcinomas, oral dysplasia and hyperkeratosis. Asian Pac J Cancer Prev. 2010;11(2):359-64. [Medline: 20843116]

6. Parapuram SK, Shi-wen X, Elliott C, Welch ID, Jones H, Baron M, Denton CP, Abraham DJ, Leask A. Loss of PTEN expression by dermal fibroblasts causes skin fibrosis. J Invest Dermatol. 2011 Oct;131(10):1996-2003. [Medline: 21654839] [doi: 10.1038/jid.2011.156]

7. Gimm O, Perren A, Weng LP, Marsh DJ, Yeh JJ, Ziebold U, Gil E, Hinze R, Delbridge L, Lees JA, Mutter GL, Robinson BG, Komminoth P, Dralle H, Eng C. Differential nuclear and cytoplasmic expression of PTEN in normal thyroid tissue, and benign and malignant epithelial thyroid tumors. Am J Pathol. 2000 May;156(5):1693-700. [Medline: 10793080] [PMC free article: 1876937] [doi: 10.1016/S0002-9440(10)65040-7]

8. Li J, Yen C, Liaw D, Podsypanina K, Bose S, Wang SI, Puc J, Miliaresis C, Rodgers L, McCombie R, Bigner SH, Giovanella BC, Ittmann M, Tycko B, Hibshoosh H, Wigler MH, Parsons R. PTEN, a putative protein tyrosine phosphatase gene mutated in human brain, breast, and prostate cancer. Science. 1997 Mar 28;275(5308):1943-7. [Medline: 9072974] [doi: $10.1126 /$ science. 275.5308 .1943 ]

9. Mutter GL, Lin MC, Fitzgerald JT, Kum JB, Baak JP, Lees JA, Weng LP, Eng C. Altered PTEN expression as a diagnostic marker for the earliest endometrial precancers. J Natl Cancer Inst. 2000 Jun 7;92(11):924-30. [Medline: 10841828] [doi: $10.1093 / \mathrm{jnci} / 92.11 .924$ ]

10. Tian Y, Li H, Qiu T, Dai J, Zhang Y, Chen J, Cai H. Loss of PTEN induces lung fibrosis via alveolar epithelial cell senescence depending on NF-KB activation. Aging Cell. 2019 Feb;18(1):e12858. [Medline: 30548445] [PMC free article: $\underline{6351835]}$ [doi: $\underline{10.1111 / a c e l .12858]}$ 
11. Chen L, Guo D. The functions of tumor suppressor PTEN in innate and adaptive immunity. Cell Mol Immunol. 2017 Jul;14(7):581-589. [Medline: 28603282] [PMC free article: 5520418] [doi: 10.1038/cmi.2017.30]

12. Rao K B, Malathi N, Narashiman S, Rajan ST. Evaluation of myofibroblasts by expression of alpha smooth muscle actin: a marker in fibrosis, dysplasia and carcinoma. J Clin Diagn Res. 2014 Apr;8(4):ZC14-7. [Medline: 24959509] [PMC free article: 4064839 ] [doi: $10.7860 / \mathrm{JCDR} / 2014 / 7820.4231]$

13. Angadi PV, Kale AD, Hallikerimath S. Evaluation of myofibroblasts in oral submucous fibrosis: correlation with disease severity. J Oral Pathol Med. 2011 Mar;40(3):208-13. [Medline: 21198872] [doi: 10.1111/j.1600-0714.2010.00995.x]

14. Miyoshi K, Yanagi S, Kawahara K, Nishio M, Tsubouchi H, Imazu Y, Koshida R, Matsumoto N, Taguchi A, Yamashita S, Suzuki A, Nakazato M. Epithelial Pten controls acute lung injury and fibrosis by regulating alveolar epithelial cell integrity. Am J Respir Crit Care Med. 2013 Feb 1;187(3):262-75. [Medline: 23239155] [doi: 10.1164/rccm.201205-08510C]

15. White ES, Atrasz RG, Hu B, Phan SH, Stambolic V, Mak TW, Hogaboam CM, Flaherty KR, Martinez FJ, Kontos CD, Toews GB. Negative regulation of myofibroblast differentiation by PTEN (Phosphatase and Tensin Homolog Deleted on chromosome 10). Am J Respir Crit Care Med. 2006 Jan 1;173(1):112-21. [Medline: 16179636] [PMC free article: 1434700] [doi: 10.1164/rccm.200507-10580C]

16. Gupta K, Metgud R, Gupta J. Evaluation of stromal myofibroblasts in oral leukoplakia, oral submucous fibrosis, and oral squamous cell carcinoma--an immunohistochemical study. J Cancer Res Ther. 2015 Oct-Dec;11(4):893-8. [Medline: 26881537] [doi: 10.4103/0973-1482.147700]

17. More CB, Gupta S, Joshi J, Varma SN. Classification system for oral submucous fibrosis. J Ind Aca Oral Med Radiol. 2012 Jan; 24(1): 24-29. [URL: https://www.jiaomr.in]

18. Lydiatt WM, Patel SG, O’Sullivan B, Brandwein MS, Ridge JA, Migliacci JC, Loomis AM, Shah JP. Head and Neck cancers-major changes in the American Joint Committee on cancer eighth edition cancer staging manual. CA Cancer J Clin. 2017 Mar;67(2):122-137. [Medline: 28128848] [doi: 10.3322/caac.21389]

19. Rooban T, Saraswathi TR, Al Zainab FH, Devi U, Eligabeth J, Ranganathan K. A light microscopic study of fibrosis involving muscle in oral submucous fibrosis. Indian J Dent Res. 2005 Oct-Dec;16(4):131-4. [Medline: 16761704] [doi: 10.4103/0970-9290.29909]

20. Neena D, Shah S, Keyuri P, Munira J. Histological grading of oral cancer: A comparison of different systems and their relation to lymph node metastasis. Nat J Commun Med. 2011 Jan; $2(1)$ : $136-42$. [URL: http://njcmindia.org/uploads/2-1 136-142.pdf]

21. Angadi PV, Krishnapillai R. Evaluation of PTEN immunoexpression in oral submucous fibrosis: role in pathogenesis and malignant transformation. Head Neck Pathol. 2012 Sep;6(3):314-21. [Medline:22392409] [PMC free article: 3422583 ] [doi: 10.1007/s12105-012-0341-z]

22. Roa I, de Toro G, Fernández F, Game A, Muñoz S, de Aretxabala X, Javle M. Inactivation of tumor suppressor gene pten in early and advanced gallbladder cancer. Diagn Pathol. 2015 Aug 21;10:148. [Medline: 26294099] [PMC free article: 4546176] [doi: 10.1186/s13000-015-0381-2]

23. Yamada KM, Araki M. Tumor suppressor PTEN: modulator of cell signaling, growth, migration and apoptosis. J Cell Sci. $2001 \mathrm{Jul} ; 114(\mathrm{Pt} 13): 2375-82$. [Medline: 11559746]

24. Squarize CH, Castilho RM, Abrahao AC, Molinolo A, Lingen MW, Gutkind JS. PTEN deficiency contributes to the development and progression of head and neck cancer. Neoplasia. 2013 May;15(5):461-71. [Medline: 23633918] [PMC free article: 3638349$]$ [doi: 10.1593/neo.121024]

25. Miyahara LAN, Pontes FSC, Burbano RMR, Conte Neto N, Guimarães DM, Fonseca FP, Pontes HAR. PTEN allelic loss is an important mechanism in the late stage of development of oral leucoplakia into oral squamous cell carcinoma. Histopathology. 2018 Jan;72(2):330-338. [Medline: 28858374] [doi: 10.1111/his.13381]

26. Afroz N, Hasan SA, Naseem S. Oral Submucous Fibrosis a Distressing Disease with Malignant Potential. Ind J Comm Med. 2006 Oct-Dec; 31(4): 270. [URL: https://www.ijcm.org.in]

27. Angadi PV, Rekha KP. Oral submucous fibrosis: a clinicopathologic review of 205 cases in Indians. Oral Maxillofac Surg. 2011 Mar;15(1):15-9. [Medline: 20414694] [doi: 10.1007/s10006-010-0225-x]

28. Siriwardena BSMS, Jayawardena KLTD, Senarath NH, Tilakaratne WM. An Evaluation of Clinical and Histopathological Aspects of Patients with Oral Submucous Fibrosis in the Background of Oral Squamous Cell Carcinoma. Biomed Res Int. 2018 Oct 9;2018:4154165. [Medline: 30402477] [PMC free article: $\underline{6198553}$ ] [doi: 10.1155/2018/4154165]

29. Acharya S, Rahman S, Hallikeri K. A retrospective study of clinicopathological features of oral squamous cell carcinoma with and without oral submucous fibrosis. J Oral Maxillofac Pathol. 2019 Jan-Apr;23(1):162. [Medline: 31110444] [PMC free article: $\underline{6503806]}$

30. Guo F, Jian XC, Zhou SH, Li N, Hu YJ, Tang ZG. [A retrospective study of oral squamous cell carcinomas originated from oral submucous fibrosis]. Zhonghua Kou Qiang Yi Xue Za Zhi. 2011 Aug;46(8):494-7. Chinese. [Medline: 22169748]

31. Payne SR, Kemp CJ. Tumor suppressor genetics. Carcinogenesis. 2005 Dec;26(12):2031-45. [Medline: 16150895] [doi: 10.1093/carcin/bgi223]

32. Thomas S, Balan A, Balaram P. The expression of retinoblastoma tumor suppressor protein in oral cancers and precancers: A clinicopathological study. Dent Res J (Isfahan). 2015 Jul-Aug;12(4):307-14. [Medline: 26288619] [PMC free article: 4533187] [doi: 10.4103/1735-3327.161427] 
33. Win SS, Nishioka M, Myint B, Takagi M. Assessment of p53 protein expression in leukoplakia, oral submucous fibrosis and oral lichen planus in Myanmar patients. Oral Med Pathol. 2005 Mar 25;10(1):15-21. [doi: 10.3353/omp.10.15]

34. Shen WH, Balajee AS, Wang J, Wu H, Eng C, Pandolfi PP, Yin Y. Essential role for nuclear PTEN in maintaining chromosomal integrity. Cell. 2007 Jan 12;128(1):157-70. [Medline: 17218262] [doi: 10.1016/j.cell.2006.11.042]

35. Jasphin SS, Desai D, Pandit S, Gonsalves NM, Nayak PB, Iype A. Immunohistochemical expression of phosphatase and tensin homolog in histologic gradings of oral squamous cell carcinoma. Contemp Clin Dent. 2016 Oct-Dec;7(4): 524-528. [Medline: 27994422] [PMC free article: 5141669] [doi: 10.4103/0976-237X.194111]

36. Chen CY, Chen J, He L, Stiles BL. PTEN: Tumor Suppressor and Metabolic Regulator. Front Endocrinol (Lausanne). 2018 Jul 9;9:338. [Medline: 30038596] [PMC free article: 6046409] [doi: 10.3389/fendo.2018.00338]

37. Tamguney T, Stokoe D. New insights into PTEN. J Cell Sci. 2007 Dec 1;120(Pt 23):4071-9. [Medline: 18032782] [doi: $10.1242 /$ jes.015230]

38. Sulis ML, Parsons R. PTEN: from pathology to biology. Trends Cell Biol. 2003 Sep;13(9):478-83. [Medline: 12946627] [doi: 10.1016/S0962-8924(03)00175-2]

39. Kurasawa Y, Shiiba M, Nakamura M, Fushimi K, Ishigami T, Bukawa H, Yokoe H, Uzawa K, Tanzawa H. PTEN expression and methylation status in oral squamous cell carcinoma. Oncol Rep. 2008 Jun;19(6):1429-34. [Medline: 18497947]

40. Mavros A, Hahn M, Wieland I, Koy S, Koufaki ON, Strelocke K, Koch R, Haroske G, Schackert HK, Eckelt U. Infrequent genetic alterations of the tumor suppressor gene PTEN/MMAC1 in squamous cell carcinoma of the oral cavity. J Oral Pathol Med. 2002 May;31(5):270-6. [Medline: 12110043] [doi: 10.1034/j.1600-0714.2002.310504.x]

41. Salmani H, Hosseini A, Azarnezhad A, Ahmad H. PTEN and p53 gene expressions in breast cancer specimens and their clinicopathological significance. Middle East J Cancer. 2018 Apr; 9(2):105-111. [doi: 10.30476/mejc.2018.42112]

42. Trotman LC, Pandolfi PP. PTEN and p53: who will get the upper hand? Cancer Cell. 2003 Feb;3(2):97-9. [Medline: 12620402] [doi: 10.1016/S1535-6108(03)00022-9]

43. Minami A, Murai T, Nakanishi A, Kitagishi Y, Ichimura M, Matsuda S. Cell Cycle Regulation via the p53, PTEN, and BRCA1 Tumor Suppressors. In: Dmitry Bulgin, editors. New Aspects in Molecular and Cellular Mechanisms of Human Carcinogenesis. IntechOpen; 2016. [doi: 10.5772/61116]

44. Nakanishi A, Kitagishi Y, Ogura Y, Matsuda S. The tumor suppressor PTEN interacts with p53 in hereditary cancer (Review). Int J Oncol. 2014 Jun;44(6):1813-9. [Medline: 24718924] [doi: 10.3892/ijo.2014.2377]

45. Puzio-Kuter AM, Laddha SV, Castillo-Martin M, Sun Y, Cordon-Cardo C, Chan CS, Levine AJ. Involvement of tumor suppressors PTEN and p53 in the formation of multiple subtypes of liposarcoma. Cell Death Differ. 2015 Nov;22(11): 1785-91. [Medline: 25822339] [PMC free article: 4648325] [doi: 10.1038/cdd.2015.27]

46. Hinz B, Phan SH, Thannickal VJ, Galli A, Bochaton-Piallat ML, Gabbiani G. The myofibroblast: one function, multiple origins. Am J Pathol. 2007 Jun;170(6):1807-16. [Medline: 17525249] [PMC free article: 1899462] [doi: 10.2353/ajpath.2007.070112]

47. Desmoulière A, Guyot C, Gabbiani G. The stroma reaction myofibroblast: a key player in the control of tumor cell behavior. Int J Dev Biol. 2004;48(5-6):509-17. [Medline: 15349825] [doi: 10.1387/ijdb.041802ad]

48. Milella M, Falcone I, Conciatori F, Cesta Incani U, Del Curatolo A, Inzerilli N, Nuzzo CM, Vaccaro V, Vari S, Cognetti F, Ciuffreda L. PTEN: Multiple Functions in Human Malignant Tumors. Front Oncol. 2015 Feb 16;5:24. [Medline: 25763354] [PMC free article: 4329810] [doi: 10.3389/fonc.2015.00024]

49. Baak JP, Van Diermen B, Steinbakk A, Janssen E, Skaland I, Mutter GL, Fiane B, Løvslett K. Lack of PTEN expression in endometrial intraepithelial neoplasia is correlated with cancer progression. Hum Pathol. 2005 May;36(5):555-61. [Medline: 15948123] [doi: 10.1016/j.humpath.2005.02.018]

50. Xie B, Zheng G, Li H, Yao X, Hong R, Li R, Yue W, Chen Y. Effects of the tumor suppressor PTEN on the pathogenesis of idiopathic pulmonary fibrosis in Chinese patients. Mol Med Rep. 2016 Mar;13(3):2715-23. [Medline: 26846484] [doi: $10.3892 / \mathrm{mmr} .2016 .4852]$

51. Alka HH, Prajakta ZR, Minal CS, Madhuri GN, Swati P, Aakruti A. Immunohistochemical analysis of tumorassociated stroma in oral squamous cell carcinoma with and without preexisting oral submucous fibrosis. J Datta Meghe Inst Med Sci Univ. 2017 Jul;12(3):170-76. [doi: 10.4103/jdmimsu.jdmimsu_8 17]

52. Mohiuddin S, Fatima N, Hosein S, Fatima N. High risk of malignant transformation of oral submucous fibrosis in Pakistani females: A potential national disaster. J Pak Med Assoc. 2016 Nov;66(11):1362-1366. [Medline: 27812049]

53. Kellermann MG, Sobral LM, da Silva SD, Zecchin KG, Graner E, Lopes MA, Kowalski LP, Coletta RD. Mutual paracrine effects of oral squamous cell carcinoma cells and normal oral fibroblasts: induction of fibroblast to myofibroblast transdifferentiation and modulation of tumor cell proliferation. Oral Oncol. 2008 May;44(5):509-17. [Medline: 17826300] [doi: 10.1016/j.oraloncology.2007.07.001]

54. Bagalad BS, Mohan Kumar KP, Puneeth HK. Myofibroblasts: Master of disguise. J Oral Maxillofac Pathol. 2017 Sep-Dec;21(3):462-463. [Medline: 29391737] [PMC free article: 5763885] [doi: 10.4103/jomfp.JOMFP 146 15]

55. Jayaraj G, Sherlin HJ, Ramani P, Premkumar P, Natesan A. Stromal myofibroblasts in oral squamous cell carcinoma and potentially malignant disorders. Indian J Cancer. 2015 Jan-Mar;52(1):87-92. [Medline: 26837985] [doi: 10.4103/0019-509X.175580]

56. Chaudhari RB. Myofibroblasts: Functions, evolution, origins, and the role in disease. SRM J Res Dent Sci. 2015 Nov;6(4):234-9. [doi: 10.4103/0976-433X.156219] 
57. Micallef L, Vedrenne N, Billet F, Coulomb B, Darby IA, Desmoulière A. The myofibroblast, multiple origins for major roles in normal and pathological tissue repair. Fibrogenesis Tissue Repair. 2012 Jun 6;5(Suppl 1):S5. [Medline: 23259712] [PMC free article: 3368789] [doi: 10.1186/1755-1536-5-S1-S5]

\section{To cite this article:}

Monteiro R, Hallikeri K, Sudhakaran A.

PTEN and $\alpha$-SMA Expression and Diagnostic Role in Oral Submucous Fibrosis and Oral Squamous Cell Carcinoma with Concomitant Oral Submucous Fibrosis

J Oral Maxillofac Res 2021;12(1):e3

URL: http://www.ejomr.org/JOMR/archives/2021/1/e3/v12n1e3.pdf

doi: $\underline{10.5037 / j o m r .2021 .12103}$

Copyright (C) Monteiro R, Hallikeri K, Sudhakaran A. Published in the JOURNAL OF ORAL \& MAXILLOFACIAL RESEARCH (http://www.ejomr.org), 31 March 2021.

This is an open-access article, first published in the JOURNAL OF ORAL \& MAXILLOFACIAL RESEARCH, distributed under the terms of the Creative Commons Attribution-Noncommercial-No Derivative Works 3.0 Unported License, which permits unrestricted non-commercial use, distribution, and reproduction in any medium, provided the original work and is properly cited. The copyright, license information and link to the original publication on (http://www.ejomr.org) must be included. 